РІЧНИК РУСКОЙ БУРСЫ

2019, Р. 15 , с. $171-182$

https://doi.org/10.12797/RRB.15.2019.15.05

Михаил Капраль

Русинськый научно-изглядователный Інстітут имени Антонія Годинкы (Будапешт)

\title{
Русинськый язык у Мадярщинї по 1989 рокови
}

\begin{abstract}
Streszczenie
Język rusiński na Węgrzech po 1989 r.

W artykule przeanalizowana została wspołczesna sytuacja językowa wśród Rusinow na Węgrzech. Zaprezentowane świadectwa zanikania dialektow rusińskich we wsiach Komloska (Комловшка) і Mucsony (Мучонь), аsymilacji językowej młodszych mieszkańcow tych miejscowości w połnocno-wschodnich Węgrzech w ostatnich dekadach. Ukazane też zostały proby rusińskich organow samorządowych, centralnego i lokalnych, korzystających z dotacji państwowych, by powstrzymać asymilację językową i wprowadzić do szkoł w obu tych miejscowościach nauczanie języka rusińskiego, a także dążenia polityków i lingwistów do skodyfikowania własnego wariantu (na wzór Rusinow z byłej Jugosławii, Słowacji i Polski) rusińskiego języka literackiego.
\end{abstract}

Słowa kluczowe: język rusiński, Węgry, kodyfikacja języka literackiego, szkoła rusińska
Abstract
The Rusyn Language in Hungary after 1989
The paper discusses the current situation of the language of Rusyns in Hun- gary. There are evidences of progressive disappearance of Rusyn dialects in villages of Komloska (Комловшка) and Mucsony (Мучонь); of language assimilation of the younger inhabitants of these places in North-Eastern Hungary in recent decades. The author also describes endeavors of Rusyns' central and local, state subsidized self-government bodies to stop language 
assimilation and bring lessons of the Rusyn language to local schools in the two villages, as well as attempts of politicians and linguists to codify their variant of the literary Rusyn language (as Rusyns from the former Yugoslavia, Slovakia, and Poland did).

Keywords: Rusyn language, Hungary, literary language codification, Rusyn school

За довгі столїтя вечша часть Русинув (за вынїмков полськых Лемкув) была пуд коронов Сятого Штефана. Не чудо, же до кунця Первуй світовуй войны, докля были частёв мадярськуй державы, они меновали себе Мадярськыма Русинами, Угроросами и т.п. ${ }^{1}$ Айбо нараз зазначиме, же бесїда у представленуй статї иде за язык днешнїх мадярськых Русинув, т. е. лем тых, котрі бывавуть у потріанонськуй Мадярщинї, и котрі на конець минулого столїтя компактно жыли лем у двох селох - Комловшцї и Мучоню, и тых, котрі привандровали на Мадяры вечшынов уже у 90-тї рокы минулого столїтя из теперь украинського Пудкарпатя. Звідавый читатель повість, же тых русинськых сел мало бы быти намного вецей, кедь попозерати на мапу, приправлену П.Р. Маґочіём (Magocsi $1996,1998)$. Смутна правда $є$ така, же по тоталнуй языковуй и значнуй народностнуй асімілації (меже тыма 3882 особами, котрі суть записанї пуд тітулом «русинська націоналность» на списованю обывательства Мадярщины 2011. рока, вечша часть не валовшна днесь анї одповісти на традіційной меже ушыткыма Русинами світа «Слава Исусу Христу») уже не найдете у тых селох (Гёрёмбёль - днесь часть Мішколца, Шайовпетрі, Шайовпалфола, Гадна, Модёровшка, Башков и т. д.) жывых носителюв русинськых діалектув. Богужаль, ипен и у наші дни языкова асімілація иде дале. Обывателї младшуй и середнюй генерації Комловшкы, не кажучы за Мучонь (у сюм богатшум рувниннум селї многі роки фунговала угляна баня, было вецей мігрантув из другых теріторій, так же языкова асімілація ишла скорі), практично не говорять по русинськы. До днесь не годен єм забыти за єдного комловшського хлопа по добруй

\footnotetext{
1 Пор., напримір, тітул письма-статї 1827. рока єдного из первых авторув, што писали за особости русинськых діалектув, Ивана Бережанина (Фогорашія) «Въ обще о различіи Славянских наръчій, собственно же о мало й карпато или Угрорусских» (Бережанинъ 1905).
} 
вусямдесятцї, котрого єм навщивив пуд час полёвых изглядовань на просьбу нїмецького колегы Ахіма Рабуса влїтї 2015. рока, котрый сегінь не знав анї єдного слова по русинськы, не позеравучы на тото, же ся родив ту и прожыв читавый вік у роднум селї.

Націоналный ренесанс мадярськых Русинув зачав ся, ги у другых сосїднїх державох, уже у 90-тї рокы минулого столїтя. И як не парадоксално на Мадярох вун успішно стартовав переже на майвысокум уровню - научнум. Парадоксално, зато же каждый из тых немногых днешнїх русиністув из посткомуністичных держав ищи и до днесь (!) добрі чуствує на собі студеной дыханя колег по цехови. Научный академичный світ намного майконзервативный, ги другі сферы сосполного жывота. Ясно, же даколы пуд страхом смерти принесенї у академичный средок по Другуй світовуй войнї сталінські традіції у русинськум вопросови, днесь, по мінімум двох генераціёх, суть цалком привычныма про вечшыну днешнїх славістув. Ясно и тото, же у модернум демократичнум світї нико у Будапештї, Братїславі, Варшаві вадь Празї не буде ся збавляти од сюй сталінськуй дїдузнины аналогічным варварськым кіпом. А тогды, на зачатку 90-ых рокув минулого столїтя ипен у сюй сфері Русины, и не лем мадярські, мали велику серенчу. Бесїда за Іштвана Удварія². Ипен сей агілный відицькый славіста у Нїредьгазькум Педаґогічнум Інстітутї имени Дёрдя Бешенєї зачав активно и велми резултативно возрождати русиністику, науку за русинську културу: історію, язык и літературу нашого народа. Сімболично, же фахман з історії и языка Русинув XVIII. столїтя зачав се робити з научнуй и сосполнуй реабілітації академика Мадярськуй Академії Наук Антонія Годинкы, рвучы сякым кіпом недобруй памняти комуністичнї традіції у науцї. Ищи 1991. рока у Нїредьгазї вун публиковав рукопись Антонія Годинкы 1922. рока Глаголниия. Сбирка всъхъ глаголовъ пудкарпатсько-русинського языка (Годинка 1991), слїдувучого 1992. выдав поєднї його бріліантнї белетристичнї рукописї, написанї автором родным южно-мараморошськым діалектом (Hodinka 1992) а 1993. рока организовав велику научну конференцію памняти

2 Педіг Іштван Удварі, основатель катедры украинськуй и русинськуй філології у Нїредьгазї, дуже уважав свого учителя, познатого мадярського славісту Ласлова Дежёва, котрый у 50-тї рокы формовав ся ги ученый ипен пуд вплывом Івана Панькевича, злого генія русинського народа, котрый ищи у первуй ловцї минулого столїтя много достигнув на полю украинизації Подкарпатськуй Руси... На свуй час се быв велми геройськый чин ученого, котрым и заслужыв правдивой честованя проф. Іштван Удварі од Русинув. 
великого Русина, матеріалы котруй вуйшли у двох книгох (Hodinka 1993; Dolgozatok 1993). Айбо майвечшым досягненям мадярського славісты, за котрой маєме быти навсе вдячнї скромному ученому из Нїредьгазы, мусиме признати заснованя ным катедры украинськуй и русинськуй філології у роднуй высшуй школї. Рішеня за ї отвореня было принятой 1992. рока а слїдувучого рока од септембра уже зачала ся пудготовка мадярськых украинистув и продовжыла ся робота у сфері русиністикы. Ипен туй за доста куртый час увидїли світло світа многі познаті днесь книгы из сюй голузы славістикыз ${ }^{3}$. Туй, напримір, были факсіміле выданї русинські бібліографічнї рідкости: букварь Мануила Олшавського (Елемента 1746) славноизвістнї букварь (Букварь 1799) и катехізіс Йоана Куткы (Катихисїсъ 1801), єдна из первых книг, писаных правдивым русинськым народным языком Антонія Годинкы (Годинка 1922?)... Меже выданыма у Нїредьгазї книгами были и такі, котрі были написанї модерным русинськым літературным языком, вечшынов пуд языковов редакціёв познатого ужгородського літератора, товмача, граматикаря и автора майуспішных русинськых словарюв Ігоря Керчы (Удварі 1999; Удварі 2002; Керча 2001).

Практично у тотї ипен рокы паралелно з дїятельством ученых на Мадярох зачали фунговати русинські сосполнї організації, котрі од 1998. рока дустали форму днешнюй сістемы русинськых органув самосправованя, котра ся пудпорує державов. Природно, же и возглавляли Русинув перву деценію на політичнум уровню родакы Комловшкы Габор Гатінгер (первый предсїдатель Вседержаного Русинського Самосправованя), Юдіта Кіш (перва предсїдатель Столичного Русинського Самосправованя), Ласлов Попович (первый предсїдатель Русинського Самосправованя Комловшкы). Ги споминать єден з фундаторув и агілных активістув русинського ренесанса кунця XX. столїтя Павел-Роберт Магочій, на І. языковум конгресї у Бардейовськых Купелёх делегація од мадярськых Русинув неговала рішеня Конгреса за твореня мадярського варіанта русинського літературного языка, выговорювучы ся тым, же перебере пак пряшовську языкову норму (Маґочій 2019, 55). Богужаль, дале обіцянок рішеня языкового вопроса про мадярськых Русинув сякым кіпом не пушло. Не было імплементованой нигда до жывота

За многочисленї выданя первуй деценії фунгованя катедры (1993-2003), позерай ту: (Káprály, PischIöger, Abonyi 2003). 
и зато, же пряшовська норма была неприйнятнов не лем про привандровавшых пудкарпатськых Русинув, котрі все агілнїше запоёвали ся до русинського сосполного двиганя у Мадярщинї, айбо и про мучонськых обывателюв русинського происходженя. Мучоняне уже тогды не мусїли чекати на кодіфікацію пряшовського варіанта літературного языка (котра ся успішно одбыла вже 1995. рока), тадь про ных намного ближша бачванська языкова норма, котра мала на тот час такой столїтню традіцію, школнї учебникы и опыт вошколованя од первуй класы и онь до высшуй школы. За тото хоть лем індіректно свідчить и учебник бачвансько-сримського варіата русинського літературного языка про мадярськых славістув мучонськуй родачкы Марії Йоббадь-Жирош Bumaŭuе y нас! (Zsirosné Jobbágy 1998). Про ню, ги и про мучонського родака Илейша Каулича, не была нияка проблема комуніковати з бачванськыма и сримськыма братами, ибо од дїточых рокув они чули ипен сяку материнську бесїду (чому єм быв свідком у Руськум Керестурі). Мучоняне, правда, видав, позад своюй майже повнуй языковуй асімілованости нигда и не вмішовали ся до языкового будованя, что не мож повісти за Комловшчан, котрі од зачатку стремили ся воздвигнути властный діалект на уровінь офіційного русинського языка у властных книгох (Гаттінгер-Клебашко 1994, 1995; Кішова 1997) и на бокох періодичных вудань свого часа («Русинскый Жывот» 1993-1999; «Вседержавный Русинскый Вісник» 1999-2002?). Додаме и тото, же у тых періодикох часто доміновали матерілы, писанї мадярськым языком. Редакторы не робили собі з того даякуй проблемы, публиковали статї иншыма славянськыма языками, днешнїма варіантами русинського літературного языка... Также нараз мусай повісти, же з языкового позора были тотї провбы не доведенї до кунця. За тото много и детално єм писав переже (Капраль 2008; Káprály 2010; Капраль 2015). Туй лем додам, же и не могли быти успішныма. На тото не доста лем хотїти, айбо треба мати хоть лем елементарнї языкові компетенції и твердо працовати на тому. Обадва комловшські авторы поетичных творув и новинарськых матеріалув доста добрі познавали родну материнську бесїду, айбо не мали достаточного, тым вецей языкового, вошколованя. У началнуй и середнюй школї учили лем словацькый и мадярськый языкы. Інтересно, же Комловшка по Другуй світовуй войнї, наколи комуністы зачали украинизовати русинські школы у сосїднюй Чехословакії и иных державох так називаного Варшавського договора, не была украинизована, так же 
ї обывателї анї не учили азбуку, у селї фунговала лем начална школа зо словацькым языком вошколованя. Не знати, ци было йсе рішеня позад економії матеріалных ресурсув (у Мадярщинї фурт фунговала сістема вошколованя на словацькум языкови), ци принимали рішеня самі Русины, про котрых словацькый язык, ги и історія и менталность сосїднёго народа были намного ближші и похопителнїші, ги закарпатськых Украинцюв. Та и самі Мадяры, тым вецей по сякых оддаленых відикох, ищи до недавна и Словакув и Русинув кликали єднако - Товтами. Само собов, же така позіція сосїдув не годна была наладити и без того доста смутну сітуацію у сфері самоідентіфікації містных Русинув. Што ся тыче языковых особостюв комловшського лемковського діалекта, то вун доста файно изглядованый Емілом Балецькым у 50-тї рокы минулого столїтя (Балецкий 1956; Балецкий 1958) и Гергейом Бенедеком у наш час (Benedek 1996; Benedek 2003). Туй лем припомняну за унікалноє у славянськум світї фонетичноє явленя: хыбеня звука [л’]. Лем у Комловшцї учуєте, напримір, на містї слова «люде» - «юде», на містї «тельо» - «теё» и т. п. Думам, же йсе вплыв мадярського языка, котрый стратив сей звук дас сперед четыристома роками. Ищи єден языковый елемент, котрый єм про ся отворив лем по вандрованю до Комловшкы послїднїх рокув: там кажуть не «двадцять пять», напримір, а «пять а двадцять». Мож повісти, же и Чехы так рахувуть, айбо у ных тото пуд нїмецькым вплывом, а де ся взяв сей языковый казус у Комловшцї? Єдно ясно, же про изглядователюв днешнїх русинськых діалектув на сїверї Мадярщины ищи все ся найде робота.

Гадка за властный варіант літературного языка зачала ся формовати меже мадярськыма Русинами по 2002 рокови, коли зачав ся публиковати новый часопис «Русинськый Світ» (зачав выходити од октовбра 2003. рока лем по русинськы каждого місяця, мадярська часть вуходжовала окремов прилогов каждї два місяцї, на днешній день вуходить 6 раз на рук, ушыткі матеріалы дублювуть ся и по мадярськы, на юній 2019. рока увидїли світло світа 137 числа новинкы).

Первый раз за вытвореня властного варіанта русинського літературного языка публично голосив автор сюй статї у фебруарі 2006. рока пуд час меженароднуй научнуй конференції на честь Антонія Годинкы (Капраль 2006а), пузднійше майдетално на тоту тему ишло ся у докладох на научных форумох, котрі были публикованї у Пряшові (Капраль 2007; Капраль 2008). 
Кедьже нияк раз не давало ся «зъєдинити» комловшськый діалект 3 мучонськым, а хоснователями русинського літературного языка в Мадярщинї вечшынов были Русины, привандровавші з Пудкарпатя, од самого зачатка быв выбраный «компілативный» пудход - формованя літературного языка на «всерусинськуй» языковуй базї. Сякым кіпом у мадярськум варіантї русинського літературного языка мож стрітити языкові елементы вшелиякуй генезы - од «уканя» ужанського и южно-мараморошського («кунь», «стул» и т. д.), восточно-русинського префікса «май» (поз. «майлїпшый» и т. д.) также родного про великого сына русинського народа, перфектного знателя южно-мараморошського говора Антонія Годинкы, напримір, з єдного бока, до западно-русинськых лексичных и граматичных елементув «кельо», «тельо», «вельо», «нич», «про», «же», «на Мадярох», «я мам», «ты маш» и т. д., з другого бока. Мы пораховали, же сяку языкову мішанину, котру само собов одмітувуть и не принимавуть рядові носителї конкретных русинськых діалектув, лем зато же ї добрі чуствувуть, не буде чуднов про тых мадярськых школашув, котрі зачинавуть русинськой вошколованя фактично од нулы (молодї Русины у Мадярщинї, богужаль, суть тотално языково асімілованї). 3 другого бока, каждый 3 днешнюй русинськуй сполности, найде у такум языкові дашто «своє».

Конкретна робота по приладженю книжок про русинськых школашув Мадярщины ${ }^{4}$ зачала ся з конверзації Віры Гіріц (Гіріц 2010). Слїдувучого рока увидїв світло світа букварь Маріанны Лявинец (Лявинец 2011). Айбо тота праца дустала читавый швунг по спеціалных «языковых» рішенёх Вседержавного Русинського Самосправованя Мадярщины и помочы державнуй програмы ТАМОР. Уже 2015. рока у спеціалізованум будапештськум выдавательстві «Croatica» увидїли світло світа нараз 5 учебникув про майменшых Русинув Мадярщины. Читанкы про 1 и 2 класы, и ку каждуй читанцї єден робочый зошит, приправленї ку печатї єдным автором (Байса 2015а; Байса 20156; Байса 2015в; Байса 2015г). Тотї учебникы про майменшых школашув суть оріентованї на максимално комунікативный аспект вошколованя. Багатї ілустрації и великой число бавок, завданок на зафарбованя и домалёваня рисункув,

4 Позад хыбеня обєктивных свідїтелств туй не будеме писати за роботу конкретных комловшськых, мучонськых и иных учителюв, котрі, кедь судити з публичных выступув містных політикув, публикацій новинок, учили вадь учать дїточок русинськуй бесїдї у недїляшных и под. школох, лїтнїх таборох, хоснувучы властнї учебнї матеріалы. 
дїточых вершыкув и співанок (котрі застаченї нотами) мавуть, на гадку авторув учебникув, мотівувати дїточок на успішный зачаток ученя материнського языка. Правда, такый пудход при зладженёви учебникув про маймолоджых ученикув ставить доста високі требованя перед учителями, котрі бы мали мати ай спеціалну аніматорську пудготовку ай музыкалнї схопности. Кедь же даколы з тых учебникув могли бы ся учити и старші, ку їх діспозіції суть двоязычнї русинсько-мадярські словарикы у кунцёви каждуй книжкы.

Про майменшых вудала свою книжочку Русинськый дїточый калейдоскоп Олга Сілцер-Ликович (Сілцер-Ликович 2016). Сесе тоненькой вуданя годно быти хосенным про учителя у недїляшных школох, на факултативных занятёх у тых школох, де неє выучованя русинського языка, вадь у дїточых лїтнїх таборох, де дїточкы лем зачинавуть учити азбуку, слухати и выговорёвати перші русинські слова.

Про русинськых школашув Мадярщины 1-4 класы также 2015. рока увидїв світло світа и учебник народописа (Заяковська Барнане, Гіріц 2015), котрый набитый багатыма текстовыма и образовыма матеріалами, котрі ілуструвуть історію русинського народа, його особостюв быта, традіцій у вшелиякых формох жывота, народнї знаня и фолклор, вірованя, обряды и обычаї. Само собов, же у учебникови не хыблять основнї співанкы и молитвы русинського народа, русинська сімболика, народнї казкы и легенды, поезія русинськых авторув од Александера Духновича и Александера Павловича до Михайла Ковача, Ивана Русенка, Василя Сочкы-Боржавина, Николая Гвозды, Габора Гатінгера, Петра Трохановського-Мурянкы, Василя Матолы и ин. У кунцёви учебника народописа окреме представлена курта інформація за днешнёсть Русинув, бывавучых у Мадярщинї.

Яло одзначити роботу ілустратора учебника, талентовануй умілкынї Агнесы Медвецькуй, котра достойно репрезентує днешнёє русинськоє малярство. Само собов, же русинськый жывопис у цїлови, годно быти, майуспішна културна сфера у минулум XX столїтю про наш народ, котрым по правдї яло ся гордити Русинам, также представленый в учебникови образами русинськых малярюв минулости и днешнёсти - Федора и Ивана Манайлув, Атаназа Фединця и Василя Скакандія.

Туй треба зазначити, же русинськой вошколованя у Мадярщинї не мож порувняти з сітуаціёв у иншых сосїднїх славянськых державох, де дїтина хоть лем дакус розуміє русинські слова, годна ся сперти на 
подобность многых языковых елементув у материнськуй бесїдї и языкови націоналнуй вечшыны у державі, котру познає каждый горожанин, ко ліпше, ко гурше. Днешнї мадярські дїти русинського происходженя суть вечшынов змадяризованыма до такуй міры, же мусай зачинати їх учити ипен так, ги дїти мадярськуй націоналности, то значить, же од нулы. Тото добрі розумівуть містнї педаґоґы, зато у Мучонськуй общеобразовнуй школї имени Ласлова Каласа, де, хоснувучы нововыданї учебникы, зачали русинськой вошколованя первыма перед трёма роками, русинськый язык учать не од первуй класы, а по четвертуй класї - од пятуй до восьмуй.

Минулого рока публикованї нараз два томы двоязычных словарюв (Ворінка-Сюч, Гіріц, Скіба 2018а; Ворінка-Сюч, Гіріц, Скіба 2018б), котрі были офіційно пудпоровані Оддїлом Образованя Рады Націоналных Меншын Мадярщины.

У цїлови треба одзначити. же в днешнюй Мадярщинї Русины мавуть надстандартнї можности на розвуй властнуй културы и вошколованя. Держава вшелияко пудпорує русинськоє націоналноє двиганя, помагать каждому, ко наміреный хранити културнї и духовнї традіції старшых генерацій. Ци будуть валовшнї мадярські Русины, не позеравучы на їх малой число и тоталну языкову асімілацію молодшых генерацій, вухосновати сякі благодатнї можности, ци стануть они у єден шор з иншыма цівілізованыма націоналностями у державі и меже єднородных братув у Централнуй Европі, т.е. зачнуть хосноваты материнську бесїду, розвивати літературный язык, укажуть уже майближші десятьлїтя.

\section{Бібліографія}

Байса, Наталія. 2015а. Наш материнськый язык. Читанка про I. класу. Budapest: Croatica.

Байса, Наталія. 20156. Наш материнськый язык. Робочьй зошылт про I. класу. Budapest: Croatica.

Байса, Наталія. 2015в. Наш материнськый язык. Читанка про II. класу. Budapest: Croatica.

Байса, Наталія. 2015г. Наш материнськый язык. Робочый зошыт про II. класу. Budapest: Croatica.

Балецкий, Эмиль. 1956. «О языковой принадлежности и заселении села Комлошка в Венгрии». Studia Slavica Academiae Scientiarum Hungaricae ч. II (2): 345-364. 
Балецкий, Эмиль. 1958. «Венгерские заимствования в лемковском говоре села Комлошка в Венгрии». Studia Slavica Academiae Scientiarum Hungaricae ч. IV (4): 23-46.

Бережанинъ, Иванъ. 1905. «Письмо-статья Ивана Бережанина къ Орлаю». В: Свънцицкій И. С. Матеріаль по исторіи возрожденія Карпатской Руси. Ч. 1. Сношенія Карпатской Руси съ Россіей въ 1-ой половинп ХІХ-аго вюка. Львовъ: Печатня Ставропигійского ин-та.

Букварь низыка рускагш съ прочӥимб руководїємб начинающихв оучитиса. Вг Будинг Пєчатано при Кралєвскомб Унївєрсітєтп Писмєны Славено-Сербскїн Tvnoграø. 1799. 1998. [Репрінт 120×170mm], Nyíregyháza.

Ворінка-Сюч, Ірина, Гіріц, Габріела, Скіба, Ірина. 2018а. Русинсько-мадярськый словарь. Budapest: Croatica.

Ворінка-Сюч, Ірина, Гіріц, Габріела, Скіба, Ірина. 2018б. Мадярсько-русинськый словарь. Budapest: Croatica.

Годинка, Антоній. 1991. Русинсько-мадярськый словарь глаголув. Глаголниия. Сбирка вспхъ глаголовъ карпатсько-русинського языка. Собравъ, упорядивъ и передословіе написав Тоній Романувъ. [1922]. Опрац., Ред. István Udvari. Nyíregyháza.

[Годинка, Антоній.] 1922?. Утиюзнина, газдуство и прошлость южнокарпатськыхъ русинувъ. Написау еденъ сокьрнииькый сирохманъ. 2000. [Репрінт 125×185 мм], Nyíregyháza.

Гаттінгер, Габор. 2015. «Дробни трагедії. Русинськый Світ ч. 114 (юлій-август): 8.

Гаттінгер-Клебашко, Габрєл. 1994. Заказана звізда (Віршы). Будапешт.

Гаттінгер-Клебашко, Габрєл. 1995. Слызы і море (віршы). Будапешт.

Гіріц, Віра. 2010. Русинська конверзація. Ред. Михаила Капраля. / Giric Vera: Ruszin Társalgás. Szerkesztette: Káprály Mihály. Aszód.

Заяковська Барнане, Марія, Гіріц, Габріела. 2015. Народопис. Учебник русинського народописа про ученикув I.-IV. класы. Budapest: Croatica.

Изученя русинського языка у Мадяршинї и за ї гатарами. Матеріалы межинародної научної конференції на честь Антонія Годинкы (10 фебруаря 2006 г.). 2006. Русинські листкы I. Ред. Михаил Капраль. Будапешт: Вуданя Вседержавного Русинського Меншинового Самосправованя у Мадярщинї и Бібліотекы Русинув Мадярщины.

Капраль, Михаил. 2006а. «Днешня языкова сітуація в Мадярщинї и Антоній Годинка». В: Изученя русинського языка у Мадярщинї и за ї гатарами. Матеріалы межинародної научної конферениії на честь Антонія Годинкы (10 фебруаря 2006 г.). Ред. Михаил Капраль 9-18. Будапешт : Вуданя Вседержавного Русинського Меншинового Самосправованя у Мадярщинї и Бібліотекы Русинув Мадярщины.

Капраль, Михаил. 2006б. «Языковый вопрос и наша школа. Слово од редактора». В: Изученя русинського языка у Мадярщинї и за ї гатарами. Матеріалы межинародної научної конференції на честь Антонія Годинкы (10 фебруаря 2006 г.). Ред. Михаил Капраль, 5-8. Будапешт: Вуданя Вседержавного Русинського Меншинового Самосправованя у Мадярщинї и Бібліотекы Русинув Мадярщины.

Капраль, Михаил. 2007. «Якый язык мають кодіфіковати мадярські Русины?» B: Jazyková kultúra a jazyková norma v rusinskom jazyku. Zbornik referátov $z$ medzi- 
národného vedeckého seminára 27-28. septembra 2007. Ред. Pliškova Anna, 85-91. Prešov: Prešovská univerzita $v$ Prešove.

Капраль, Михаіл. 2008. «Днешня языкова сітуація в Мадярщинї». В: Pусиньскьй язык меджі двома коньресами. Збірник ребератів з III. Меджінародного коньресу русиньского языка, Краків, 13-16.9.2007. Ред. Анна Плїшкова, 73-79. Пряшів: Пряшівска універзіта в Пряшові - Інштітут русиньского языка і културы.

Капраль, Михаил. 2015. «Кодіфікація модерного русинського літературного языка в Мадярщинї». В: Русиньскый літературный язык на Словакії. 20 років кодіфбікаиіі. Зборник ребератів з IV. Міджінародного коньресу русиньского языка. Ред. Кветослава Копорова, 90-97. Пряшів: Пряшівска універзіта в Пряшові - Інштітут русиньского языка і културы.

Капраль, Михаил. 2017. Русинськый ортолрафічный словарь (з sраматичныма таблами). Выдає: Русинськый Научный Інстітут имени Антонія Годинкы при Вседержавному Русинському Самосправованю / A ruszin helyesírási szótár (nyelvtani táblázatokkal). Szerkesztő: Káprály Mihály. Kiadja: Országos Ruszin Önkormányzat Hodinka Antal Ruszin Tudományos Intézet. Budapest.

Катихисїст малый или наука православно-хртїанскал сокращєнная. Во благочєстноє воспитанїє юношества Дїєєєсї мункачовскї Составлєннал въ Оунгварть. Въ Будинг градю Пєчатано писмєны Крал. Всєучилища Пєштанскагш, 1801. 1997. [Репрінт 140×200 mm], Nyíregyháza.

Керча, Ігорь. 2001. Матящ, король Русинув / Mátyás, aruszinok királya. / Az elöszót írta és szerkesztette: Udvari István. Studia Ukrainica et Rusinica Nyíregyháziensia 8. Nyíregyháza.

Кішова, Юдіта. 1997. Звук душі. Будапешт: Етникум.

Лявинец, Маріанна. 2011. Русинськый букварь про школашув Мадяршины. Пуд редакціёв М. Капраля. / Lyavinecz Mariann A. 1997. Ruszin ábécékönyv magyarországi iskolások számára. Szerkesztette Dr. Káprály Mihály. Budapest.

Магочій, Павел-Роберт. 2018. «Кодіфікачный процес русиньского языка: досягнутя і новы задачі». В: 20 років высокошкольской русиністікы на Словакії. Зборник рефератів з меджінародной научной конференції. Ред. Кветослава Копорова, $43-$ 66. Prešov: Vydavatel'stvo Prešovskej univerzity.

Сілцер-Ликович, Олга. 2016. Русинськый дїмочьй калейдоскоп. Будапешт.

Удварі, Іштван. 1999. Русинські жерела урбарської реформы Марії Теризї, Studia Ukrainica et Rusinica Nyíregyháziensia 6. Nyíregyháza.

Удварі, Іштван. 2002. Збирька жерел про студї русинського писемства I. Кириличні уббіжникь мукачовського єпископа Андрія Бачинського. Редіковав Isорь Керча. Szöveggyüjteménya ruszin írásbeliség tanulmányozásához. I. Bacsinszky Andrásmunkácsi megyéspüspök cirillbetüs körlevelei, Studia Ukrainica et Rusinica Nyíregyháziensia 12. Нїредьгаза.

Benedek, Gergely. 1996. «Egy északkelet-magyarországi ruszin település: Komlóska etnikai és nyelvi dimenziói». B: Katona Judit - Viga gyula (szerk.): Az interetnikus kapcsolatok kutatásának újabb eredményei. 319-323. Miskolc. 
Benedek, Gergely. 2003. «Язык и диалект». Studia Slavica Academiae Scientiarum Hungaricae, ч. 48 (1-3): 11-24.

Dolgozatok Hodinka Antal tiszteletére. Szerkesztette: Udvari István, Studia Ukrainica et Rusinica Nyíregyháziensia I. Nyíregyháza, 1993.

Hodinka Antal válogatott kéziratai. Выбрані рукописі Антонія Годинкы. Vál. szerk. és a bev. életrajzot írta Udvari István. Vasvári Pál Társaság füzetei 11. Nyíregyháza, 1992.

Hodinka Antal Emlékkönyv. Tanulmányok Hodinka Antal tiszteletére. Ред. Istvan Udvari. Nyíregyháza, 1993.

Elementa puerilis institutionis in lingva latina. Claudiopoli Typis Academ. Soc. JESU per Andream Feij Anno 1746. Начало писменъ дътємъ къ наставлєнїю на Латинскомъ њзыкъ. Повєлєнїємъ и накладомъ Боголюбиваго КҮР Михайла Манайла Олшавски Єппа Росєискаго, Мукач. и Марамороскаго над Людми Восточнаго Набоженства во Оуграх. Напєчатасл въ Коложварской Типографїи льта ГднА А〉мs. 1999. [Репрінт, 95×155 mm], Nyíregyháza.

Káprály, Mihály, Pischlöger, Kristian, Abonyi, Andrea. 2003. Ukrán és Ruszin Filológiai Tanszék. Kiadványok: 1993-2003. Кафедра украинской и русинской филологии. Публикации: 1993-2003. Lehrstuhl für Ukrainistik und Russinistik. Publikationen: 19932003 / Szerk. Káprály Mihály; az elöszót írta Székely Gábor. (Studia Ukrainica et Rusinica Nyíregyháziensia 13). Nyíregyháza.

Káprály, Mihály. 2010. «Rusínsky jazyk v Mad’arsku». B: Papp Anna Mária (szerk.). Kevésbé használt nyelvek helyzete a Visegrádi Négyek országaiban, 88-94. Budapest: OIK.

Magocsi, Paul Robert. 1996, 1998. Carpatho-Rusyn settlement at the outset of the 20th century with additional data from 1881 and 1806 / Росселеня Карпатьскьх Русинів на зачатку ХХ столітя з далшыма данныма з 1881-го і 1806-го року. Produced by the Cartography Office, University of Toronto.

Zsirosné Dr. Jobbágy, Mária. 1998. Ismerjenek meg minket! 15 bács-szerémi ruszin nyelvlecke. Szerkesztette: Udvari István / Мария Йоббадь-Жирош. 1998. Витайце y нас! 15 лекциї бачванско-сримского языка. Nyíregyháza. 